\title{
EFFECTS OF MANAGEMENT PRACTICES ON GRASSLAND BIRDS:
}

\section{NELSON'S SHARP-TAILED SPARROW}

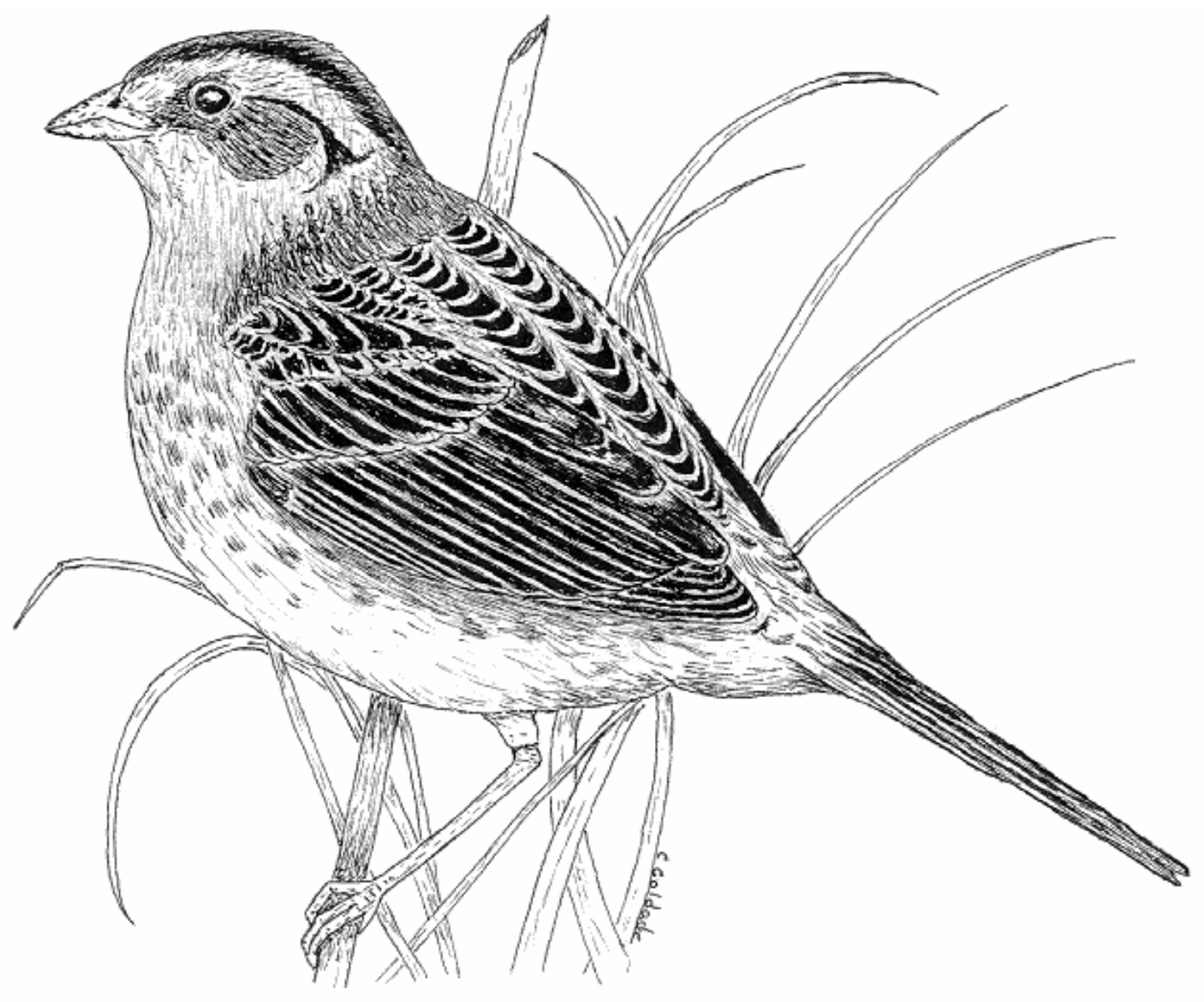

Grasslands Ecosystem Initiative

Northern Prairie Wildlife Research Center

U.S. Geological Survey

Jamestown, North Dakota 58401 
This report is one in a series of literature syntheses on North American grassland birds. The need for these reports was identified by the Prairie Pothole Joint Venture (PPJV), a part of the North American Waterfowl Management Plan. The PPJV recently adopted a new goal, to stabilize or increase populations of declining grassland- and wetland-associated wildlife species in the Prairie Pothole Region. To further that objective, it is essential to understand the habitat needs of birds other than waterfowl, and how management practices affect their habitats. The focus of these reports is on management of breeding habitat, particularly in the northern Great Plains.

Suggested citation:

Dechant, J. A., M. L. Sondreal, D. H. Johnson, L. D. Igl, C. M. Goldade, P. A. Rabie, and B. R. Euliss. 1999 (revised 2002). Effects of management practices on grassland birds: Nelson's Sharp-tailed Sparrow. Northern Prairie Wildlife Research Center, Jamestown, ND. 12 pages.

Species for which syntheses are available or are in preparation:

American Bittern

Mountain Plover

Marbled Godwit

Long-billed Curlew

Willet

Wilson's Phalarope

Upland Sandpiper

Greater Prairie-Chicken

Lesser Prairie-Chicken

Northern Harrier

Swainson's Hawk

Ferruginous Hawk

Short-eared Owl

Burrowing Owl

Horned Lark

Sedge Wren

Loggerhead Shrike

Sprague's Pipit
Grasshopper Sparrow

Baird's Sparrow

Henslow's Sparrow

Le Conte's Sparrow

Nelson's Sharp-tailed Sparrow

Vesper Sparrow

Savannah Sparrow

Lark Sparrow

Field Sparrow

Clay-colored Sparrow

Chestnut-collared Longspur

McCown's Longspur

Dickcissel

Lark Bunting

Bobolink

Eastern Meadowlark

Western Meadowlark

Brown-headed Cowbird 


\title{
EFFECTS OF MANAGEMENT PRACTICES ON GRASSLAND BIRDS:
}

\author{
NELSON'S SHARP-TAILED SPARROW
}

Jill A. Dechant, Marriah L. Sondreal, Douglas H. Johnson, Lawrence D. Igl, Christopher M. Goldade, Paul A. Rabie, and Betty R. Euliss

Series Coordinator: Douglas H. Johnson

Series Assistant Coordinator: Lawrence D. Igl

Reviewers: David R. C. Prescott and James D. Rising

Range Map: Jeff T. Price

Cover Art: Christopher M. Goldade

Major Funding: Prairie Pothole Joint Venture, U.S. Fish and Wildlife Service U.S. Geological Survey

Funding also provided by: U.S. Forest Service The Nature Conservancy

\section{Collaborators:}

Louis B. Best, Iowa State University

Carl E. Bock, University of Colorado

Brenda C. Dale, Canadian Wildlife Service

Stephen K. Davis, Saskatchewan Wetland Conservation Corporation

James J. Dinsmore, Iowa State University

James K. Herkert, Illinois Endangered Species Protection Board

Fritz L. Knopf, Midcontinent Ecological Science Center

Rolf R. Koford, Iowa Cooperative Fish and Wildlife Research Unit

David R. C. Prescott, Alberta NAWMP Centre

Mark R. Ryan, University of Missouri

David W. Sample, Wisconsin Department of Natural Resources

David A. Swanson, Ohio Division of Wildlife

Peter D. Vickery, Massachusetts Audubon Society

John L. Zimmerman (retired), Kansas State University

March 1999

(revised January 2002) 


\section{ORGANIZATION AND FEATURES OF THIS SPECIES ACCOUNT}

Information on the habitat requirements and effects of habitat management on grassland birds were summarized from information in more than 4,000 published and unpublished papers. A range map is provided to indicate the relative densities of the species in North America, based on Breeding Bird Survey (BBS) data. Although birds frequently are observed outside the breeding range indicated, the maps are intended to show areas where managers might concentrate their attention. It may be ineffectual to manage habitat at a site for a species that rarely occurs in an area. The species account begins with a brief capsule statement, which provides the fundamental components or keys to management for the species. A section on breeding range outlines the current breeding distribution of the species in North America, including areas that could not be mapped using BBS data. The suitable habitat section describes the breeding habitat and occasionally microhabitat characteristics of the species, especially those habitats that occur in the Great Plains. Details on habitat and microhabitat requirements often provide clues to how a species will respond to a particular management practice. A table near the end of the account complements the section on suitable habitat, and lists the specific habitat characteristics for the species by individual studies. A special section on prey habitat is included for those predatory species that have more specific prey requirements. The area requirements section provides details on territory and home range sizes, minimum area requirements, and the effects of patch size, edges, and other landscape and habitat features on abundance and productivity. It may be futile to manage a small block of suitable habitat for a species that has minimum area requirements that are larger than the area being managed. The Brown-headed Cowbird (Molothrus ater) is an obligate brood parasite of many grassland birds. The section on cowbird brood parasitism summarizes rates of cowbird parasitism, host responses to parasitism, and factors that influence parasitism, such as nest concealment and host density. The impact of management depends, in part, upon a species' nesting phenology and biology. The section on breeding-season phenology and site fidelity includes details on spring arrival and fall departure for migratory populations in the Great Plains, peak breeding periods, the tendency to renest after nest failure or success, and the propensity to return to a previous breeding site. The duration and timing of breeding varies among regions and years. Species' response to management summarizes the current knowledge and major findings in the literature on the effects of different management practices on the species. The section on management recommendations complements the previous section and summarizes specific recommendations for habitat management provided in the literature. If management recommendations differ in different portions of the species' breeding range, recommendations are given separately by region. The literature cited contains references to published and unpublished literature on the management effects and habitat requirements of the species. This section is not meant to be a complete bibliography; a searchable, annotated bibliography of published and unpublished papers dealing with habitat needs of grassland birds and their responses to habitat management is posted at the Web site mentioned below.

This report has been downloaded from the Northern Prairie Wildlife Research Center WorldWide Web site, www.npwrc.usgs.gov/resource/literatr/grasbird/grasbird.htm. Please direct comments and suggestions to Douglas H. Johnson, Northern Prairie Wildlife Research Center, U.S. Geological Survey, 8711 37th Street SE, Jamestown, North Dakota 58401; telephone: 701253-5539; fax: 701-253-5553; e-mail: Douglas_H_Johnson@usgs.gov. 


\section{NELSON'S SHARP-TAILED SPARROW}

(Ammodramus nelsoni nelsoni)

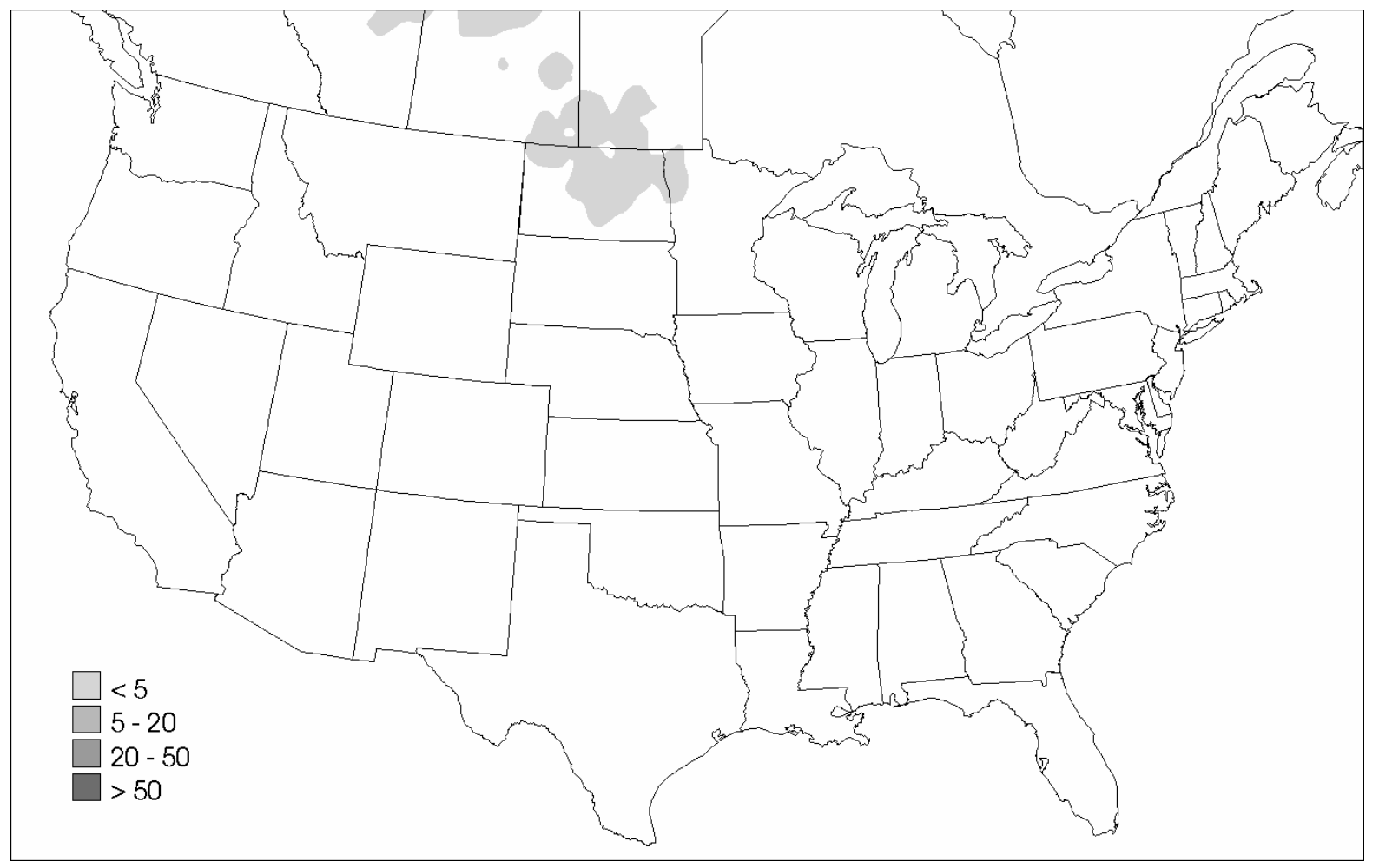

Figure. Breeding distribution of the Nelson's Sharp-tailed Sparrow (Ammodramus nelsoni nelsoni) in the United States and southern Canada, based on Breeding Bird Survey data, 1985-1991. Scale represents average number of individuals detected per route per year. Map from Price, J., S. Droege, and A. Price. 1995. The summer atlas of North American birds. Academic Press, London, England. 364 pages.

Keys to management include providing dense grasses or emergent vegetation near damp areas or freshwater wetlands.

\section{Breeding range:}

In 1995, Sharp-tailed Sparrow (Ammodramus caudacutus) was split into two species, Saltmarsh Sharp-tailed Sparrow (A. caudacutus) and Nelson's Sharp-tailed Sparrow (A. nelsoni) (AOU 1995). This account deals only with the subspecies of Nelson's Sharp-tailed Sparrow, A. n. nelsoni, that breeds in freshwater wetlands and damp areas in northcentral North America. The subspecies A. n. alterus and A. $n$. subvirgatus occur outside of the region of focus, the Great Plains.

Nelson's Sharp-tailed Sparrows (A. n. nelsoni) breed from the southern Northwest Territories and northeastern British Columbia through Alberta, northwestern and southcentral Saskatchewan, and southern Manitoba, south to northeastern Montana, North Dakota, and northeastern South Dakota, and east to northwestern Minnesota (National Geographic Society 1987). (See figure for the relative densities of Nelson's Sharp-tailed Sparrows in the United States and southern Canada, based on Breeding Bird Survey data.) 
Suitable habitat:

Nelson's Sharp-tailed Sparrows are secretive, are unpredictable singers, and are difficult to detect when not singing (Breckenridge 1930; Greenlaw and Rising 1994; D. R. C. Prescott, Land Stewardship Centre of Canada, St. Albert, Alberta, pers. comm.). Consequently, they are difficult to survey, and knowledge of their habitat preferences is limited mostly to notes of incidental observations. In Alberta, no Nelson's Sharp-tailed Sparrows were detected during daytime fixed-point-radius counts on study plots, or during surveys that used North American Breeding Bird Survey methodology (Prescott et al. 1993). Moderate numbers, however, were detected during surveys of wetlands conducted $0.5 \mathrm{hr}$ after sunset.

Nelson's Sharp-tailed Sparrows prefer freshwater wetlands with dense, emergent vegetation or damp areas with dense grasses (Bownan 1904, Murray 1969, Stewart 1975, Krapu and Green 1978, Knapton 1979, Williams and Zimmer 1992, Berkey et al. 1993). Suitable habitat includes fens, wet meadows, peatlands, lake margins with emergent cattails (Typha), native prairie, idle fields, and planted cover (e.g., Conservation Reserve Program lands and dense nesting cover [DNC]), but habitat use may vary annually depending on moisture conditions (Bownan 1904; Breckenridge and Kilgore 1929; Roberts 1932; Hill 1968; Stewart 1975; Salt and Salt 1976; Knapton 1979; Renken 1983; Johnson and Schwartz 1993; Hartley 1994a,b; Prescott et al. 1995; Prescott and Murphy 1999).

Nests usually are built in stands of grasses with litter that is persistent from year to year (Greenlaw and Rising 1994). Nests are built on or slightly above the ground in damp areas among emergent vegetation (Murray 1969, Stewart 1975). In North Dakota, Nelson's Sharptailed Sparrows are more abundant in dry years than in wet years (Stewart 1975). In dry years, they nest in the shallow-marsh and deep-marsh zones of wetlands; in wet years, they nest in cordgrass (Spartina) within wet-meadow zones. Breeding populations in fens are restricted to areas dominated by cattail, reed (Phragmites), and softstem bulrush (Schoenoplectus tabernaemontani); species that provide nesting cover within shallow-marsh and deep-marsh zones include cattail, hardstem bulrush (Schoenoplectus acutus), river bulrush (Schoenoplectus fluviatilis), alkali bulrush (Scirpus maritimus), sprangletop (Scolochloa festucacea), sloughgrass (Beckmannia), slough sedge (Carex atherodes), and marsh smartweed (Polygonum amphibium). In North Dakota, Nelson's Sharp-tailed Sparrows were common in prairie cordgrass (Spartina pectinata) stands, occurred at the edges of common reed (Phragmites australis) stands, and nested in sprangletop (Murray 1969). Nelson's Sharp-tailed Sparrows in northeastern North Dakota nested in thin, sparse grass on a wet alkali flat (Rolfe 1899, Hill 1968). They were found nesting in bulrushes (Scirpus) and dense grass in South Dakota (Williams and Zimmer 1992). In Alberta, abundances of Nelson's Sharp-tailed Sparrows in mixed-grass prairie were similar to those in tame grasslands (Prescott et al. 1995). In Minnesota and Canada, Nelson's Sharp-tailed Sparrows nested in wetlands located in wooded areas (Breckenridge 1930, Salt and Wilk 1958, Salt and Salt 1976).

In Minnesota, Breckenridge and Kilgore (1929) observed Nelson's Sharp-tailed Sparrows nesting in vegetation above damp soil on the edge of a 500-ha wetland dominated by moss (Sphagnum) and sedge (Carex). Another Minnesota study found that graminoid density within breeding territories was high ( $>180 \mathrm{stems} / \mathrm{m}^{2}$ ) (Hanowski and Niemi 1988). Stem density of phanerophytes (graminoids, forbs, or shrubs $>40 \mathrm{~cm}$ tall that are present each year) was low (mean of 0.06 stems $/ \mathrm{m}^{2}$ ) in habitats used by Nelson's Sharp-tailed Sparrows (Hanowski and Niemi 1988). The most common forbs near nests were mints (Lamiaceae); the phanerophytes 
comprised broad-leaved cattails (Typha latifolia) and willows (Salix spp.). Nests in northwestern Minnesota were in wetlands surrounded by bands of tamarack (Larix laricina), thickets of aspen (Populus), and patches of tallgrass (Breckenridge 1930). Nelson's Sharp-tailed Sparrows in the St. Croix River Valley of Minnesota and Wisconsin used northern sedge meadows containing mannagrass (Glyceria), bluejoint (Calamagrostis canadensis), and water sedge (Carex aquatilis) (Faanes 1981). A table near the end of the account lists the specific habitat characteristics for Nelson’s Sharp-tailed Sparrows by study.

\section{Area requirements:}

Little information is available regarding the area requirements of Nelson's Sharp-tailed Sparrows. No studies have investigated a relationship between patch size and nest success or patch size and rates of brood parasitism by Brown-headed Cowbirds (Molothrus ater). Nelson's Sharp-tailed Sparrows are colonial nesters, and have been suggested to be non-territorial (Murray 1969, Greenlaw and Rising 1994). However, they do respond to recorded playbacks of songs, which suggests some territoriality (D. R. C. Prescott, pers. comm.). They are interspecifically territorial with Le Conte's Sparrows (Ammodramus leconteii) (Murray 1969; D. R. C. Prescott, pers. comm.). In northern Minnesota, the average wetland size used by Nelson's Sharp-tailed Sparrows was 130 ha (range was from 15 to 250 ha) (Hanowski and Niemi 1986). Nelson's Sharp-tailed Sparrows also were found in a 500-ha wetland (Breckenridge and Kilgore 1929). In southcentral North Dakota, Nelson's Sharp-tailed Sparrows occurred on wetlands ranging in size from 5.0 to 6.4 ha (Krapu and Green 1978).

\section{Brown-headed Cowbird brood parasitism:}

The only record of brood parasitism by Brown-headed Cowbirds was that of a single egg discovered in a nest in Manitoba (Hill 1968).

\section{Breeding-season phenology and site fidelity:}

Nelson's Sharp-tailed Sparrows arrive on the breeding grounds from early to mid-May in Minnesota, from mid- to late May in North Dakota and the aspen parkland of Alberta, and not before June in southeastern Saskatchewan and southwestern Manitoba (Roberts 1932; Murray 1969; Salt and Salt 1976; Knapton 1979; D. R. C. Prescott, pers. comm.). In North Dakota, the peak breeding season is mid-June to early August (Murray 1969, Stewart 1975). Nelson’s Sharp-tailed Sparrows leave the breeding grounds from late August to mid-October (Roberts 1932, Murray 1969, Salt and Salt 1976, Greenlaw and Rising 1994). Saltmarsh Sharp-tailed Sparrows on the East Coast raise second broods and renest following failed nests (Greenlaw and Rising 1994), but renesting has not been reported for Nelson's Sharp-tailed Sparrow.

Limited evidence exists in North Dakota for breeding-site fidelity (Murray 1969). One of three banded males and the only banded female returned to a study site in the year after they were banded. Saltmarsh Sharp-tailed Sparrows on the East Coast exhibited strong breeding-site fidelity, with 53-60\% (sample size not given) of both sexes returning to the same marsh in which they initially were captured (Greenlaw and Rising 1994). Many of these birds returned to the same area of the marsh where they had been captured. 
Species' response to management:

Few studies have examined the effects of burning, mowing, or grazing on Nelson's Sharp-tailed Sparrow. Greenlaw and Rising (1994) have suggested that removal of vegetation by burning or mowing may cause local extirpation of populations.

In Alberta aspen parkland, Nelson's Sharp-tailed Sparrows were absent from mixed-grass pasture and uncommon in tame pasture (Prescott and Murphy 1996). Tame pastures were characterized by lower percentages of grass and shrub cover, higher percentages of forb cover and bare ground, fewer shrub clumps, and taller grasses and forbs than mixed-grass pastures (Prescott and Murphy 1996). The effects of three intensities of late-season (dates were not provided) grazing were examined in Alberta (Prescott 1996). The only Nelson's Sharp-tailed Sparrow recorded was on a site subjected to the highest intensity of grazing (biomass loss due to grazing was 71\%, but vegetation height was not reduced significantly).

In North Dakota, Nelson's Sharp-tailed Sparrows were present in DNC planted to tame species and absent in idle and grazed mixed-grass prairie (Renken 1983, Renken and Dinsmore 1987). DNC was characterized by taller and denser vegetation cover and a deeper litter layer than idle mixed-grass (Renken 1983). Nelson’s Sharp-tailed Sparrows in Alberta were more abundant in seeded-native DNC than in tame DNC (Prescott et al. 1995). In Saskatchewan, Nelson's Sharp-tailed Sparrows were present in seeded-native and tame DNC and in native mixed-grass, but were absent from wheat fields (Hartley 1994a,b). In a Manitoba study comparing abundance of Nelson's Sharp-tailed Sparrows in idle native grassland, tame DNC, and seeded-native DNC, the species was detected only in native grassland (Dhol et al. 1994). In another Manitoba study, which compared seeded-native DNC, DNC planted to tame grasses and legumes, hayland planted to tame grasses and legumes, and idle native grassland, Nelson's Sharp-tailed Sparrows were recorded only in hayland (single occurrence) (Jones 1994). The species was rare or absent in tame DNC $<2$ yr old in Alberta; abundance increased with age of DNC until the fifth year, after which abundance decreased (Prescott and Murphy 1999). In North Dakota, South Dakota, and Minnesota, Nelson's Sharp-tailed Sparrows were present at low densities in Conservation Reserve Program fields (Johnson and Schwartz 1993; Igl and Johnson, unpublished data).

\section{Management Recommendations:}

Protect wetlands from drainage (Greenlaw and Rising 1994).

Prevent removal of vegetation through burning or harvesting, or increase ground cover in areas where short grasses prevail (Greenlaw and Rising 1994, Prescott and Murphy 1996). 
Table. Nelson's Sharp-tailed Sparrow habitat characteristics.

\begin{tabular}{|c|c|c|c|}
\hline Author(s) & Location(s) & Habitat(s) Studied* & Species-specific Habitat Characteristics \\
\hline Bownan 1904 & North Dakota & Idle, wetland & Inhabited dense clumps of grass near wetlands \\
\hline $\begin{array}{l}\text { Breckenridge and Kilgore } \\
1929\end{array}$ & Minnesota & Idle, wetland & $\begin{array}{l}\text { Nested in vegetation above damp soil on the edge of a 500-ha } \\
\text { wetland dominated by moss (Sphagnum) and sedge (Carex) }\end{array}$ \\
\hline Dhol et al. 1994 & Manitoba & $\begin{array}{l}\text { Dense nesting cover } \\
\text { (DNC; idle seeded- } \\
\text { native, idle tame), } \\
\text { idle mixed-grass }\end{array}$ & $\begin{array}{l}\text { Single occurrence in idle mixed-grass; absent from seeded- } \\
\text { native and tame DNC; mixed-grass grasslands had average } \\
\text { vegetation values of } 6.8 \mathrm{~cm} \text { litter depth and } 27.5 \mathrm{~cm} \\
\text { vegetation height; percent cover of dominant plant species } \\
\text { were } 2.5 \% \text { slender wheatgrass (Agropyron caninum), } 7.3 \% \\
\text { western wheatgrass (Pascopyrum smithii), } 1.7 \% \text { green } \\
\text { needlegrass (Stipa viridula), } 21 \% \text { Kentucky bluegrass (Poa } \\
\text { pratensis), 7.9\% smooth brome (Bromus inermis), 9.1\% } \\
\text { Baltic rush (Juncus balticus), and 6.2\% sedge (Carex spp.) }\end{array}$ \\
\hline Faanes 1981 & $\begin{array}{l}\text { Minnesota, } \\
\text { Wisconsin }\end{array}$ & $\begin{array}{l}\text { Cropland, idle, idle } \\
\text { tallgrass/tame, shrub } \\
\text { carr, tame hayland, } \\
\text { tame pasture, wet } \\
\text { meadow, wetland, } \\
\text { woodland }\end{array}$ & $\begin{array}{l}\text { Nested in sedge meadow with mannagrass (Glyceria), } \\
\text { bluejoint (Calamagrostis canadensis), and water sedge } \\
\text { (Carex aquatilis) }\end{array}$ \\
\hline $\begin{array}{l}\text { Hanowski and Niemi } \\
\text { 1986, 1988; } \\
\text { Niemi and Hanowski } \\
1983\end{array}$ & Minnesota & $\begin{array}{l}\text { Idle tallgrass, } \\
\text { peatland, shrub carr, } \\
\text { wetland }\end{array}$ & $\begin{array}{l}\text { Used areas with average habitat variables as follows: } 9.9 \% \\
\text { ground cover, } 121.9 \mathrm{~cm} \text { vegetation height, } 11.7 \mathrm{~cm} \text { water } \\
\text { depth, } 53 \mathrm{~cm} \text { phanerophyte (shrubs, forbs, or graminoids }>40 \\
\mathrm{~cm} \text { tall and present each year) height, and } 130 \text { ha wetland } \\
\text { size; mean density measurements were } 181.9 \mathrm{stems} / \mathrm{m}^{2} \\
\text { graminoids, } 17.2 \mathrm{stems} / \mathrm{m}^{2} \text { forbs, and } 0.06 \mathrm{stems} / \mathrm{m}^{2} \\
\text { phanerophytes; coverages of forb species were } 76 \% \text { mint } \\
\text { (Lamiaceae), } 10 \% \text { bur-reed (Sparganium spp.), } 5 \% \text { parsley }\end{array}$ \\
\hline
\end{tabular}




\begin{tabular}{|c|c|c|c|}
\hline & & & $\begin{array}{l}\text { (Apiaceae), 5\% thistle (Cirsium spp.), 1\% blue flag (Iris } \\
\text { versicolor), 1\% purple marshlocks (Comarum palustre), 1\% } \\
\text { clover (Trifolium spp.), and 1\% bedstraw (Galium); } \\
\text { coverages of phanerophytes were 79\% willow (Salix), 15\% } \\
\text { quaking aspen (Populus tremuloides), and 6\% common reed } \\
\text { (Phragmites australis) }\end{array}$ \\
\hline Hartley $1994 a, b$ & Saskatchewan & $\begin{array}{l}\text { Cropland, DNC (idle } \\
\text { seeded-native, idle } \\
\text { seeded-native/tame, } \\
\text { idle tame), idle } \\
\text { mixed-grass, idle } \\
\text { tame hayland }\end{array}$ & Used idle mixed-grass and DNC; absent from cropland \\
\hline Hill 1968 & Rangewide & $\begin{array}{l}\text { Idle mixed-grass, } \\
\text { wetland, woodland }\end{array}$ & $\begin{array}{l}\text { Nested in freshwater wetlands and in short, sparse grass on } \\
\text { alkali flats in mixed-grass prairie }\end{array}$ \\
\hline Jones 1994 & Manitoba & $\begin{array}{l}\text { Cropland, DNC (idle } \\
\text { seeded-native, idle } \\
\text { tame), idle mixed- } \\
\text { grass, idle tame, tame } \\
\text { hayland }\end{array}$ & Observed only in tame hayland \\
\hline Knapton 1979 & $\begin{array}{l}\text { Manitoba, } \\
\text { Saskatchewan }\end{array}$ & $\begin{array}{l}\text { Hayland, idle, } \\
\text { wetland }\end{array}$ & Occupied idle wet areas and created wetlands \\
\hline Murray 1969 & North Dakota & $\begin{array}{l}\text { Wetland, } \\
\text { wet- meadow } \\
\text { hayland }\end{array}$ & $\begin{array}{l}\text { Inhabited freshwater wetlands; were common in stands of } \\
\text { prairie cordgrass (Spartina pectinata); also occurred in } \\
\text { sprangletop (Scolochloa festucaceae) and at the edges of } \\
\text { stands of common reed; the only nest observed was in a stand } \\
\text { of sprangletop; were absent from upland areas }\end{array}$ \\
\hline $\begin{array}{l}\text { Prescott and Murphy } \\
1996\end{array}$ & Alberta & $\begin{array}{l}\text { Mixed-grass pasture, } \\
\text { tame pasture }\end{array}$ & $\begin{array}{l}\text { Were absent from native pasture and uncommon in tame } \\
\text { pasture; compared to native pasture, tame pasture had lower }\end{array}$ \\
\hline
\end{tabular}




\begin{tabular}{|c|c|c|c|}
\hline & & & $\begin{array}{l}\text { grass cover }(58 \%) \text {, lower shrub cover }(4.5 \%) \text {, higher forb } \\
\text { cover }(24 \%) \text {, more bare ground }(13 \%) \text {, fewer shrub clumps } \\
(0.6 \text { clumps/ha), taller grasses }(20 \mathrm{~cm}) \text {, taller forbs }(17 \mathrm{~cm}) \text {, } \\
\text { and taller total herbaceous growth }(20 \mathrm{~cm}) \text { (all values are } \\
\text { means) }\end{array}$ \\
\hline $\begin{array}{l}\text { Prescott and Murphy } \\
1999\end{array}$ & Alberta & $\begin{array}{l}\text { Cropland, DNC (idle } \\
\text { seeded-native/tame) }\end{array}$ & $\begin{array}{l}\text { Were absent from DNC }<2 \text { yr old; abundance increased with } \\
\text { age of DNC from 2- to 5-yr-old DNC, after which abundance } \\
\text { decreased }\end{array}$ \\
\hline Prescott et al. 1995 & Alberta & $\begin{array}{l}\text { Aspen parkland, } \\
\text { cropland, DNC (idle } \\
\text { seeded-native, idle } \\
\text { tame), idle mixed- } \\
\text { grass, idle tame, } \\
\text { mixed-grass pasture, } \\
\text { tame hayland, tame } \\
\text { pasture, wetland, } \\
\text { woodland }\end{array}$ & $\begin{array}{l}\text { Were most abundant in seeded-native DNC, followed by } \\
\text { tame DNC, idle tame grassland, idle mixed-grass, large ( }>8 \\
\text { ha) saline wetlands, and small ( }<1 \text { ha) fresh wetlands; absent } \\
\text { from brush/shrub, continuously grazed mixed-grass, } \\
\text { continuously grazed native parkland, cropland, deferred- } \\
\text { grazed (grazed only after } 15 \text { July) mixed-grass, deferred- } \\
\text { grazed tame grassland, deferred-mowed hayfields, idle } \\
\text { deciduous upland, idle native parkland, large freshwater } \\
\text { wetlands, medium (1-8 ha) freshwater wetlands, medium } \\
\text { saline wetlands, shelterbelts, small saline wetlands, and tame } \\
\text { pasture }\end{array}$ \\
\hline $\begin{array}{l}\text { Renken 1983, } \\
\text { Renken and Dinsmore } \\
1987\end{array}$ & North Dakota & $\begin{array}{l}\text { DNC (idle seeded- } \\
\text { native, idle tame), } \\
\text { mixed-grass pasture }\end{array}$ & $\begin{array}{l}\text { Present only in tame DNC; occupied plots had taller and } \\
\text { denser vegetation than unoccupied plots; average vegetation } \\
\text { values in occupied plots were } 89 \% \text { grass cover, } 35 \% \text { forb } \\
\text { cover, } 99 \% \text { litter cover, } 0 \% \text { shrub cover, } 0.3 \% \text { bare ground, } \\
41 \mathrm{~cm} \text { effective vegetation height, and } 2.4 \mathrm{~cm} \text { litter depth }\end{array}$ \\
\hline Roberts 1932 & Minnesota & $\begin{array}{l}\text { Wetland, wet } \\
\text { meadow }\end{array}$ & Used shallow wetlands \\
\hline Rolfe 1899 & North Dakota & $\begin{array}{l}\text { Idle mixed-grass, } \\
\text { wetland }\end{array}$ & $\begin{array}{l}\text { Nested in short, sparse grass on an alkali flat in wet mixed- } \\
\text { grass prairie }\end{array}$ \\
\hline
\end{tabular}




\begin{tabular}{|l|l|l|l|}
\hline Stewart 1975 & North Dakota & $\begin{array}{l}\text { Wet meadow, } \\
\text { wetland }\end{array}$ & $\begin{array}{l}\text { During dry years, nested in shallow- and deep-marsh wetland } \\
\text { zones dominated by cattails (Typha spp.), sprangletop, } \\
\text { American sloughgrass (Beckmannia syzigachne), slough } \\
\text { sedge (Carex atherodes), marsh smartweed (Polygonum } \\
\text { amphibium) and bulrushes (Scirpus spp.); during wet years, } \\
\text { nested in wet-meadow zones dominated by prairie cordgrass }\end{array}$ \\
\hline $\begin{array}{l}\text { Williams and Zimmer } \\
1992\end{array}$ & South Dakota & $\begin{array}{l}\text { Wet meadow, } \\
\text { wetland }\end{array}$ & $\begin{array}{l}\text { Nested in bulrush (Scirpus) and dense grass adjacent to } \\
\text { wetland }\end{array}$ \\
\hline
\end{tabular}

*In an effort to standardize terminology among studies, various descriptors were used to denote the management or type of habitat. "Idle" used as a modifier (e.g., idle tallgrass) denotes undisturbed or unmanaged (e.g., not burned, mowed, or grazed) areas. "Idle" by itself denotes unmanaged areas in which the plant species were not mentioned. Examples of "idle" habitats include weedy or fallow areas (e.g., oldfields), fencerows, grassed waterways, terraces, ditches, and road rights-of-way. "Tame" denotes introduced plant species (e.g., smooth brome [Bromus inermis]) that are not native to North American prairies. "Hayland" refers to any habitat that was mowed, regardless of whether the resulting cut vegetation was removed. "Burned" includes habitats that were burned intentionally or accidentally or those burned by natural forces (e.g., lightning). In situations where there are two or more descriptors (e.g., idle tame hayland), the first descriptor modifies the following descriptors. For example, idle tame hayland is habitat that is usually mowed annually but happened to be undisturbed during the year of the study. 


\section{LITERATURE CITED}

American Ornithologists’ Union (AOU). 1995. Fortieth supplement to the American Ornithologists’ Union Check-list of North American birds. Auk 112:819-830.

Berkey, G., R. Crawford, S. Galipeau, D. Johnson, D. Lambeth, and R. Kreil. 1993. A review of wildlife management practices in North Dakota: effects on nongame bird populations and habitats. Report submitted to Region 6. U.S. Fish and Wildlife Service, Denver, Colorado. 51 pages.

Bownan, C. W. 1904. Nelson’s Sharp-tailed Sparrow in North Dakota. Auk 21:385-386.

Breckenridge, W. J. 1930. Breeding of Nelson’s Sparrow (Ammospiza nelsoni) with special reference to Minnesota. Occasional Paper of the Museum of Natural History, University of Minnesota 3:29-38.

Breckenridge, W. J., and W. Kilgore. 1929. Nelson’s Sparrow nesting in Minnesota. Auk 46:548.

Dhol, S., J. Horton, and R. E. Jones. 1994. 1994 non-waterfowl evaluation of Manitoba’s North American Waterfowl Management Plan. Unpublished report. Wildlife Branch, Manitoba Department of Natural Resources, Winnipeg, Manitoba. 12 pages.

Faanes, C. A. 1981. Birds of the St. Croix River Valley: Minnesota and Wisconsin. U.S. Fish and Wildlife Service, Washington, D.C. North American Fauna 73. 196 pages.

Greenlaw, J. S., and J. D. Rising. 1994 . Sharp-tailed Sparrow (Ammodramus caudacutus). In A. Poole and F. Gill, editors. The birds of North America, No. 112. The Academy of Natural Sciences, Philadelphia, Pennsylvania; The American Ornithologists’ Union, Washington, D.C.

Hanowski, J. M., and G. J. Niemi. 1986. Habitat characteristics for bird species of special concern. Unpublished report to Minnesota Department of Natural Resources, St. Paul, Minnesota. 50 pages.

Hanowski, J. M., and G. J. Niemi. 1988. An approach for quantifying habitat characteristics for rare wetland birds. Pages 51-56 in Ecosystem management: rare and endangered species and significant habitats. Proceedings of the 15th annual Natural Areas Conference.

Hartley, M. J. 1994a. Passerine abundance and productivity indices in grasslands managed for waterfowl nesting cover. Transactions of the North American Wildlife and Natural Resources Conference 59:322-327.

Hartley, M. J. 1994b. Passerine abundance and productivity indices in grasslands managed for waterfowl nesting cover in Saskatchewan, Canada. M.S. thesis. Louisiana State University, Baton Rouge, Louisiana. 42 pages. 
Hill, N. P. 1968. Nelson's Sharp-tailed Sparrow. Pages 815-819 in O. L. Austin, Jr., editor. Life histories of North American cardinals, grosbeaks, buntings, towhees, finches, sparrows, and allies. Dover Publications Inc., New York, New York.

Johnson, D. H., and M. D. Schwartz. 1993. The Conservation Reserve Program: habitat for grassland birds. Great Plains Research 3:273-295.

Jones, R. E. 1994. Non-waterfowl evaluation of Manitoba’s North American Waterfowl Management Program. Unpublished report. Wildlife Branch, Manitoba Department of Natural Resources, Winnipeg, Manitoba. 15 pages.

Knapton, R. W. 1979. Birds of the Gainsborough-Lyleton region. Saskatchewan Natural History Society Special Publication 10. 72 pages.

Krapu, G. L., and R. K. Green. 1978. Breeding bird populations of selected semipermanent wetlands in south-central North Dakota. American Birds 32:110-112.

Murray, B. G., Jr. 1969. A comparative study of Le Conte’s and Sharp-tailed sparrows. Auk 86:199-231.

National Geographic Society. 1987. Field guide to the birds of North America, second edition. National Geographic Society, Washington, D.C. 464 pages.

Niemi, G. J., and J. M. Hanowski. 1983. Habitat characteristics of Yellow Rail, Upland Sandpiper, and Sharp-tailed Sparrow territories. Lake Superior Basin Studies Center, University of Minnesota, Duluth, Minnesota. 15 pages.

Prescott, D. R. C. 1996. Impacts of grazing management on bird communities of dense nesting cover: the Alberta Agricultural Development Corporation (AADC) property. Alberta NAWMP Centre and Land Stewardship Centre of Canada. NAWMP-027. Edmonton, Alberta. 15 pages.

Prescott, D. R. C., R. Arbuckle, B. Goddard, and A. Murphy. 1993. Methods for the monitoring and assessment of avian communities on NAWMP landscapes in Alberta, and 1993 results. NAWMP-007. Alberta NAWMP Centre, Edmonton, Alberta. 48 pages.

Prescott, D. R. C., and A. J. Murphy. 1996. Habitat associations of grassland birds on native and tame pastures of the aspen parkland in Alberta. NAWMP-021. Alberta NAWMP Centre, Edmonton, Alberta. 36 pages.

Prescott, D. R. C., and A. Murphy. 1999. Bird populations in seeded nesting cover on North American Waterfowl Management Plan properties in the aspen parkland of Alberta. Pages 203-210 in P. D. Vickery and J. R. Herkert, editors. Ecology and conservation of grassland birds of the Western Hemisphere. Studies in Avian Biology 19.

Prescott, D. R. C., A. J. Murphy, and E. Ewaschuk. 1995. An avian community approach to determining biodiversity values of NAWMP habitats in the aspen parkland of Alberta. Alberta NAWMP Centre. NAWMP-012. Edmonton, Alberta. 58 pages. 
Renken, R. B. 1983. Breeding bird communities and bird-habitat associations on North Dakota waterfowl production areas of three habitat types. M.S. thesis. Iowa State University, Ames, Iowa. 90 pages.

Renken, R. B., and J. J. Dinsmore. 1987. Nongame bird communities on managed grasslands in North Dakota. Canadian Field-Naturalist 101:551-557.

Roberts, T. S. 1932. The birds of Minnesota, Volume 2. University of Minnesota Press, Minneapolis, Minnesota. 821 pages.

Rolfe, E. S. 1899. Nesting of Nelson's Sparrow (Ammodramus nelsoni) in North Dakota. Auk 16:356-357.

Salt, W. R., and J. R. Salt. 1976. The birds of Alberta. Hurtig Publishers, Edmonton, Alberta. 498 pages.

Salt, W. R., and A. L. Wilk. 1958. The birds of Alberta. Department of Economic Affairs, Edmonton, Alberta. 295 pages.

Stewart, R. E. 1975. Breeding birds of North Dakota. Tri-College Center for Environmental Studies, Fargo, North Dakota. 295 pages.

Williams, J. D., and M. Zimmer. 1992. First Sharp-tailed Sparrow South Dakota nesting record. South Dakota Bird Notes 44:84-85. 